\title{
Gambaran Tingkat Pengetahuan tentang Pterygium pada Pengendara Bentor di Kecamatan Mananggu
}

\author{
Dewinta P. Ama, ${ }^{1}$ Rillya D. P. Manoppo, ${ }^{2}$ Wenny P. Supit ${ }^{2}$ \\ ${ }^{1}$ Program Studi Pendidikan Dokter Fakultas Kedokteran Universitas Sam Ratulangi, Manado, \\ Sulawesi Utara, Indonesia \\ ${ }^{2}$ Bagian Ilmu Kesehatan Mata Fakultas Kedokteran Universitas Sam Ratulangi, Manado, \\ Sulawesi Utara, Indonesia \\ Email: dewintapramilia@gmail.com
}

\begin{abstract}
Pterygium is a degenerative and invasive fibrovascular tissue growth in bulbar conjunctiva triggered by ultraviolet rays, therefore, outdoor activities for a long period may increase the risk of pterygium. This study was aimed to obtain an overview of knowledge levels regarding pterygium among bentor drivers at Mananggu District. This was a descriptive and survey study. Samples were 36 respondents who met the inclusion criteria, collected by using the accidental sampling technique. Data of respondents were obtained by using questionnaires of 10 questions related to pterygium and then were analyzed by using the univariate analysis. The results showed that 8 respondents $(22.2 \%)$ had good knowledge level, 14 respondents (38.9\%) had fair knowledge level, and 14 respondents (38.9\%) had poor knowledge level. In conclusion, most of bentor drivers at Mananggu district did not have good knowledge level regarding pterygium
\end{abstract}

Keywords: pterygium, knowledge level, bentor drivers

\begin{abstract}
Abstrak: Pterigium merupakan suatu pertumbuhan jaringan fibrovaskular pada konjungtiva bulbar yang bersifat degeneratif dan invasif. Faktor utama pemicu terjadinya pterigium ialah sinar ultraviolet sehingga beraktivitas diluar ruangan dalam waktu yang cukup lama dapat meningkatkan risiko terjadinya pterigium. Penelitian ini bertujuan untuk memperoleh gambaran tingkat pengetahuan tentang pterigium pada pengendara bentor di Kecamatan Mananggu. Jenis penelitian ialah survei deskriptif. Sampel penelitian diambil menggunakan teknik accidental sampling dan diperoleh 36 responden yang memenuhi kriteria inklusi. Data penelitian diperoleh melalui kuesioner yang berisi 10 pertanyaan terkait pterigium dan dianalisis secara univariat. Terdapat 8 responden $(22,2 \%)$ memiliki tingkat pengetahuan baik mengenai pterigium, 14 responden $(38,9 \%)$ memiliki tingkat pengetahuan cukup, dan 14 responden $(38,9 \%)$ memiliki tingkat pengetahuan kurang. Simpulan penelitian ialah sebagian besar pengendara bentor di Kecamatan Mananggu belum memiliki tingkat pengetahuan yang baik mengenai pterigium

Kata kunci: pterigium, tingkat pengetahuan, pengendara bentor
\end{abstract}

\section{PENDAHULUAN}

Pterigium merupakan suatu partumbuhan jaringan fibrovaskular pada konjungtiva bulbar yang bersifat degeneratif dan invasif. Pterigium memiliki bentuk seperti sayap dengan bagian puncak menghadap ke sentral kornea, sehingga dalam partumbuhannya pterigium dapat meluas ke bagian kornea. ${ }^{1,2}$ Pada tahap awal pterigium biasanya tidak memberikan gejala atau memberi gejala ringan seperti mata terasa panas, sering merah, terasa menganjal seperti ada benda asing, dan pada tahap yang lebih lanjut dapat terjadi penurunan tajam penglihatan akibat astigmatisme bahkan kebutaan karena sumbu penglihatan kornea tertutup dengan jaringan fibrovaskular. ${ }^{3-5}$

Prevalensi pterigium di seluruh dunia 
berkisar antara 0,3-36\%, dan pada tahun 2000 dilaporkan lebih dari 200 juta orang di seluruh dunia didiagnosis dengan pterigium. ${ }^{3,6}$ Berdasarkan hasil Riskesdas 2013 prevalensi pterigium di Indonesia sebesar $8,3 \%$, dengan prevalensi tertinggi di Bali $(25,2 \%)$, diikuti Maluku (18,0\%), dan Nusa Tenggara Barat $(17,0 \%){ }^{7}$ Etiologi terjadinya pterigium belum diketahui dengan jelas, namun terdapat beberapa faktor risiko yang dikaitkan dengan terjadinya pterigium seperti lingkungan kerja, usia tua, jenis kelamin laki-laki, tinggal di daerah beriklim kering berangin, dan paparan sinar ultraviolet yang tinggi. ${ }^{3}$ Faktor utama yang diperkirakan menjadi penyebab pterigium ialah sinar ultraviolet. Hal ini dikemukakan karena terdapat insiden kejadian pterigium yang lebih tinggi pada daerah dekat ekuator, yang memperoleh paparan sinar matahari yang lebih tinggi. ${ }^{8}$ Penelitian terdahulu juga mendapatkan adanya hubungan masa kerja terhadap kejadian pterigium, dimana subjek yang bekerja dibawah paparan sinar matahari lebih dari 5 jam perhari 7 kali lebih berisiko terkena pterigium. $^{9}$

Di provinsi Gorontalo terdapat tranportasi umum yang menjadi ciri khas Kota Gorontalo, disebut bentor (Gambar 1). ${ }^{10}$ Masyarakat yang bekerja sebagai pengendara bentor umumnya memiliki lebih banyak aktivitas di luar ruangan sehingga memungkinkan para pengendara bentor mendapat paparan sinar ultraviolet yang lebih banyak dengan durasi yang lebih lama. Prevalensi pterigium di Gorontalo menempati urutan ke 12 dari 33 provinsi dengan prevalensi $<10 \%$.

Terkait keterangan yang telah dipaparkan, dilakukan survei awal pada 6 orang pengendara bentor di Kecamatan Mananggu yang terkena pterigium. Pada wawancara singkat didapatkan para pengendara bentor tidak mengetahui apa yang dimaksud dengan pterigium, faktor risiko, upaya pencegahan pterigium, dan dampak yang bisa timbul akibat pterigium. Berdasarkan hal tersebut maka penulis tertarik untuk meneliti gambaran tingkat pengetahuan tentang pterigium pada pengendara bentor di Kecamatan Mananggu Kota Gorontalo.

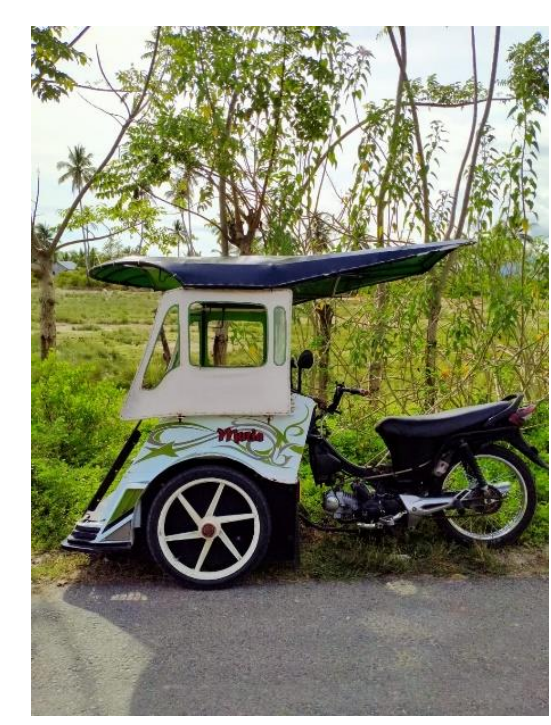

Gambar 1. Sebuah bentor di Kecamatan Mananggu Kota Gorontalo

\section{METODE PENELITIAN}

Penelitian ini dilaksanakan di Kecamatan Mananggu, Kabupaten Boalemo, Provinsi Gorontalo pada tahun 2020. Jenis penelitian ini ialah survei deskriptif. Responden ialah pengendara bentor di kecamatan Mananggu yang memenuhi kriteria inklusi, diambil menggunakan teknik accidental sampling. Instrumen penelitian yang digunakan ialah kuesioner yang berisi data demografi responden dan 10 pertanyaan terkait pterigium yang telah divalidasi. Data dari kuesioner selanjutnya dianalisis menggunakan uji deskriptif statistik untuk melihat distribusi frekuensi dan persentase. Hasil analisis data pengetahuan kemudian dikategorikan ke dalam 3 kategori tingkat pengetahuan menurut Arikunto (2013) (Tabel 1). ${ }^{11}$

Tabel 1. Kategori tingkat pengetahuan ${ }^{11}$

\begin{tabular}{cc}
\hline $\begin{array}{c}\text { Persentase } \\
\text { pencapaian } \\
\text { kuesioner }(\%)\end{array}$ & $\begin{array}{c}\text { Kategori tingkat } \\
\text { pengetahuan }\end{array}$ \\
\hline $76-100$ & Baik \\
$56-75$ & Cukup \\
$<56$ & Kurang \\
\hline
\end{tabular}

\section{HASIL PENELITIAN}

Responden yang berpartisipasi dalam penelitian ini berjumlah 36 pengendara bentor. Seluruh responden berjenis kelamin 
laki-laki dan sebagian besar berasal dari kelompok usia 26-35 tahun (50\%). Pendidikan terakhir responden paling banyak yaitu SMP $(41,7 \%)$.

Tabel 2 memperlihatkan bahwa sebanyak 8 responden $(22,2 \%)$ memiliki tingkat pengetahuan baik, dan masing-masing sebanyak 14 responden $(38,9 \%)$ memiliki tingkat pengetahuan cukup dan kurang.

Tabel 2. Distribusi tingkat pengetahuan responden

\begin{tabular}{ccc}
\hline $\begin{array}{c}\text { Tingkat } \\
\text { pengetahuan }\end{array}$ & $\begin{array}{c}\text { Frekuensi } \\
(\mathbf{n})\end{array}$ & $\begin{array}{c}\text { Persentase } \\
(\boldsymbol{\%})\end{array}$ \\
\hline Baik & 8 & 22,2 \\
Cukup & 14 & 38,9 \\
Kurang & 14 & 38,9 \\
Total & 36 & 100 \\
\hline
\end{tabular}

Tabel 3 memperlihatkan bahwa responden pada kelompok usia 26-35 tahun (dewasa awal) yang terbanyak memiliki tingkat pengetahuan kategori cukup $(22,2 \%)$, disusul oleh kelompok usia 36-45 tahun (dewasa akhir) dengan tingkat pengetahuan kategori kurang $(13,9 \%)$, dan kelompok usia 46-55 tahun (lansia awal) dengan tingkat pengetahuan kategori kurang $(8,3 \%)$. Pada kelompok usia 17-25 tahun (remaja akhir) hanya terdapat 1 responden $(2,8 \%)$ dengan tingkat pengetahuan kategori baik, sedangkan pada kelompok usia 56-65 tahun (lansia akhir) hanya terdapat 1 responden $(2,8 \%)$ dengan tingkat pengetahuan kategori cukup.

Tabel 4 memperlihatkan bahwa responden berpendidikan terakhir SD paling banyak memiliki tingkat pengetahuan kategori kurang $(25 \%)$, responden berpendidikan terakhir SMP paling banyak memiliki tingkat pengetahuan kategori cukup $(19,4 \%)$, sedangkan responden berpendidikan terakhir SMA paling banyak memiliki tingkat pengetahuan kategori baik $(11,1 \%)$. Terdapat juga responden yang tidak bersekolah yaitu sebanyak 1 responden $(2,8 \%)$ dan memiliki tingkat pengetahuan kategori kurang.

Tabel 3. Distribusi tingkat pengetahuan responden berdasarkan usia

\begin{tabular}{ccccccccc}
\hline Usia & \multicolumn{4}{c}{ Tingkat Pengetahuan } & \multicolumn{2}{c}{ Total } \\
& \multicolumn{2}{c}{ baik } & \multicolumn{2}{c}{ cukup } & \multicolumn{2}{c}{ kurang } & & \\
& $\mathrm{n}$ & $\%$ & $\mathrm{n}$ & $\%$ & $\mathrm{n}$ & $\%$ & $\mathrm{n}$ & $\%$ \\
\hline 17-25 tahun & 1 & 2,8 & 0 & 0 & 0 & 0 & 1 & 2,8 \\
26-35 tahun & 4 & 11,1 & 8 & 22,2 & 6 & 16,7 & 18 & 50,0 \\
36-45 tahun & 2 & 5,6 & 4 & 11,1 & 5 & 13,9 & 11 & 30,6 \\
46-55 tahun & 1 & 2,8 & 1 & 2,8 & 3 & 8,3 & 5 & 13,9 \\
56-65 tahun & 0 & 0 & 1 & 2,8 & 0 & 0 & 1 & 2,8 \\
Total & 8 & 22,2 & 14 & 38,9 & 14 & 38,9 & 36 & 100 \\
\hline
\end{tabular}

Tabel 4. Distribusi tingkat pengetahuan berdasarkan pendidikan terakhir

\begin{tabular}{ccccccccc}
\hline $\begin{array}{c}\text { Pendidikan } \\
\text { terakhir }\end{array}$ & \multicolumn{4}{c}{ Tingkat Pengetahuan } & \multicolumn{2}{c}{ Total } \\
& \multicolumn{2}{c}{ baik } & \multicolumn{2}{c}{ cukup } & \multicolumn{2}{c}{ kurang } & & \\
& $\mathrm{n}$ & $\%$ & $\%$ & $\mathrm{n}$ & $\%$ & $\mathrm{n}$ & $\%$ \\
\hline Tidak & 0 & 0 & 0 & 0 & 1 & 2,8 & 1 & 2,8 \\
bersekolah & & & & & & & & \\
SD & 2 & 5,6 & 4 & 11,1 & 9 & 25,0 & 15 & 50,0 \\
SMP & 2 & 5,6 & 7 & 19,4 & 2 & 5,6 & 11 & 30,6 \\
SMA & 4 & 11,1 & 3 & 8,3 & 2 & 5,6 & 9 & 13,9 \\
Total & 8 & 22,2 & 14 & 38,9 & 14 & 38,9 & 36 & 100 \\
\hline
\end{tabular}




\section{BAHASAN}

Menurut Notoatmodjo, pengetahuan merupakan hasil dari tahu, dan itu terjadi setelah seseorang melakukan penginderaan terhadap suatu objek tertentu, yang sebagian besar diperoleh melalui indera pendengaran dan indera penglihatan. ${ }^{12}$ Dari hasil penilaian kuesioner penelitian sebagian besar responden tidak tahu bahwa sinar matahari merupakan faktor penyebab terjadinya pterigium sehingga mereka tidak tahu bahwa pekerjaan di luar ruangan lebih berisiko terkena pterigium. Selain itu responden juga tidak mengetahui bagaimana cara mencegah pterigium. Hal ini dikarenakan kurangnya informasi mengenai pterigium yang didapatkan oleh responden, baik dalam bentuk lisan dari tenaga kesehatan maupun dalam bentuk tulisan dari artikel atau brosur kesehatan. Akibatnya responden yang sehari-hari bekerja sebagai pengendara bentor tidak melakukan tindakan pencegahan seperti menggunakan topi dan kacamata saat sedang bekerja.

Menurut teori, seseorang mengadopsi suatu perilaku apabila ia memiliki pengetahuan tentang apa arti atau manfaat perilaku tersebut bagi dirinya sendiri dan keluarga. Penelitian oleh Rogers (1974) mengungkapkan bahwa perilaku yang didasari oleh pengetahuan akan lebih bertahan lama dari pada perilaku yang tidak didasari dengan pengetahuan. ${ }^{12}$ Dikatakan juga bahwa semakin bertambah usia semakin baik pengetahuan seseorang. ${ }^{13}$ Namun pada penelitian ini tidak didapatkan hal serupa (Tabel 3). Bertambahnya usia tidak membuat seseorang memiliki pengetahuan yang lebih baik. Hal ini dikarenakan banyak faktor yang dapat memengaruhi pengetahuan seseorang, misalnya dari faktor eksternal yang meliputi pendidikan, sumber informasi, sosial, budaya dan ekonomi serta lingkungan. Selain itu, usia merupakan salah satu faktor risiko terjadinya pterigium. Angka kejadian pterigium terus meningkat seiring dengan bertambahnya usia. ${ }^{7}$ Oleh karena itu sangat penting untuk meningkatkan pengetahuan tentang pterigium kepada masyarakat agar dapat melakukan tindakan pencegahan sejak dini.
Hasil penelitian ini menunjukkan bahwa semakin tinggi tingkat pendidikan seseorang maka semakin baik pengetahuan tentang pterigium yang dimiliki. Hasil ini sejalan dengan teori yang menyatakan bahwa makin tinggi pendidikan seseorang, maka makin mudah orang tersebut menerima informasi. ${ }^{13}$ Dengan demikian seseorang dengan pendidikan yang lebih tinggi akan memiliki pengetahuan yang lebih baik.

Dari wawancara singkat yang dilakukan oleh peneliti kepada beberapa responden, diketahui bahwa responden masih kurang mencari tahu tentang pterigium dan peranan dari tenaga kesehatan dalam memberi edukasi masih sangat kurang. Oleh karena itu penting untuk meningkatkan pengetahuan tentang pterigium kepada masyarakat terutama yang memiliki pekerjaan di luar ruangan, agar masyarakat dapat melakukan tindakan pencegahan sedini mungkin.

\section{SIMPULAN}

Sebagian besar pengendara bentor di Kecamatan Mananggu Kota Gorontalo belum memiliki tingkat pengetahuan yang baik mengenai pterigium.

Diperlukan peran aktif dari tenaga kesehatan setempat dalam memberi edukasi tentang faktor risiko pterigium, dampak, serta cara pencegahannya kepada masyarakat terutama bagi yang bekerja diluar ruangan

\section{Konflik Kepentingan}

Penulis menyatakan tidak terdapat konflik kepentingan dalam studi ini.

\section{DAFTAR PUSTAKA}

1. Lestari DJT, Sari DR, Mahdi PD, Himayani R. Pterigium derajat IV pada pasien geriatri. Majority. 2017;7:20-5.

2. de Lima FVI, Manuputty AG. Hubungan paparan sinar matahari dengan angka kejadian pterigium di desa Waai kabupaten Maluku tengah tahun 2013. Molucca Medica. 2014;4(2):101-9.

3. Anbesse DH, Kassa T, Kefyalew B, Tasew A, Atnie A, Desta B. Prevalence and associated factors of pterygium among adults living in Gondar city, Northwest Ethiopia. PLoS ONE [Internet]. 2017; 12(3):1-9. 
4. Agrasidi PA, Triningrat AAMP. Karakteristik penderita pterigium di desa Tianyar Karangasem tahun 2015. E-Jurnal Medika [Internet]. 2018;7(7):1-6. Available from: http://ojs.unud.ac.id/index.php/ eum

5. Erry, Mulyani UA, Susilowati D. Distribusi dan karakteristik pterigium di Indonesia. Buletin Penelitian Sistem Kesehatan. 2011;14:84-9.

6. Pan Z, Cui J, Shan G, Chou Y, Pan L, Sun Z, et al. Prevalence and risk factors for pterygium: A cross-sectional study in Han and Manchu ethnic populations in Hebei, China. BMJ Open. 2019;9(2):112.

7. Riset kesehatan dasar 2013. Jakarta: Badan Penelitian dan Pengembangan Kesehatan Kementerian Kesehatan RI; 2013.

8. Hanifah ESN, Ibrahim, Saleh MI. Korelasi paparan sinar matahari dengan derajat pterigium di rumah sakit khusus mata provinsi Sumatera Selatan periode
2015-2016. Majalah Kedokteran Sriwijaya. 2018;1:20-5.

9. Rany N. Hubungan lingkungan kerja dan perilaku nelayan dengan kejadian pterygium di desa Kemang kecamatan Pangkalan Kuras kabupaten Pelalawan. Jurnal Kesehatan Komunitas [Internet]. 2017; 3(4):153-8.

10. Mudana IK, Heriwibowo D. Pengoprasian becak motor (bentor) di wilayah kota Gorontalo. Warta Penelitian Perhubungan. 2016;28(2):130-45.

11. Jabar JM, Nursafitri S. Tingkat pengetahuan petani tentang sinar UV terhadap kesehatan mata. Sehat Masada Journal. 2019;13(1):32-9.

12. Notoatmodjo S. Promosi Kesehatan dan Perilaku Kesehatan (Edisi Revisi). Jakarta: PT. Rineka Cipta, 2014.

13. Budiman, Riyanto A. Pengetahuan dan Sikap dalam Penelitian Kesehatan. Jakarta: Salemba Medika, 2013. 